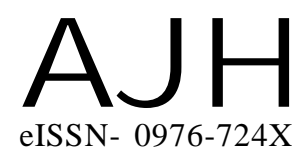

Received : 22.06.2015

Revised : 21.10 .2015

Accepted : 07.11.2015

Members of the Research Forum

Associated Authors:

${ }^{1}$ Department of Horticulture Science,

Faculty of Agriculture, Annamalai

University, CHIDAMBARAM (T.N.)

INDIA

Author for correspondence : JOHNSON NAOREM

Department of Horticulture Science,

Faculty of Agriculture, Annamalai

University, CHIDAMBARAM (T.N.)

INDIA
THE ASIAN JOURNALOF HORTICULTURE

Volume 10 | Issue 2 | December, 2015 | 207-211

Visit us -www.researchjournal.co.in

\title{
Effect of phosphorus and potassium on growth and yield characters of bitter gourd (Momordica charantia L.) ecotype 'Mithipagal'
}

\section{JOHNSON NAOREM AND R. SURESHKUMAR ${ }^{1}$}

ABSTRACT : An experiment on effect of phosphorus and potassium on growth and yield characters of bitter gourd ecotype 'Mithipagal' was carried out with the four levels of phosphorus $\left(0,30,60\right.$ and $\left.90 \mathrm{~kg} \mathrm{ha}^{-1}\right)$ and three levels of potassium $\left(0,40\right.$ and $\left.80 \mathrm{~kg} \mathrm{ha}^{-1}\right)$ comprised of twelve treatment combinations under Factorial Randomized Block Design with three replications. Nitrogen @ $90 \mathrm{~kg} \mathrm{ha}^{-1}$ was applied in all treatments as constant dose except the control. Among the graded levels, $\mathrm{P}_{3} \mathrm{~K}_{2}$ (Phosphorus $90 \mathrm{~kg} \mathrm{ha}^{-1}+$ Potassium $80 \mathrm{~kg} \mathrm{ha}^{-1}$ ) registered the maximum values in growth parameters viz., vine length, number of branches plant ${ }^{-1}$, number of leaves plant ${ }^{-1}$. However, it was closely followed by $\mathrm{P}_{2} \mathrm{~K}_{2}$. The maximum values of physiological characters were found with the treatment combination of $\mathrm{P}_{3} \mathrm{~K}_{2}$, which registered the maximum leaf area index, total chlorophyll content, photosynthetic rate and dry matter production.

KEY WORDS : Bitter gourd, Momordica charantia, Growth, Yield

HOW TO CITE THIS ARTICLE : Naorem, Johnson and Sureshkumar, R. (2015). Effect of phosphorus and potassium on growth and yield characters of bitter gourd (Momordica charantia L.) ecotype 'Mithipagal'. Asian J. Hort., 10(2) : 207-211. 